$\mathrm{MD}$

49,1

130

\title{
Strategic capabilities, competitive strategy, and performance among retailers in Argentina, Peru and the United States
}

\author{
John A. Parnell \\ CENTRUM Católica, Pontificia Universidad Católica del Perú, Lima, Peru
}

\begin{abstract}
Purpose - This paper aims to assess the influence of strategic capabilities on the business strategy-performance relationship among retail businesses in Argentina, Peru, and the USA.

Design/methodology/approach - Zahra and Covin's self-reported scale was amended and utilized to categorize businesses along Porter's typology. Strategic capability scales were adopted from DeSarbo and associates. Self-reporting scales to assess relative competitive and objective performance in the present study were adopted from Ramanujam and Venkatraman. A survey containing these scales was administered to 277 attendees at a retail trade show in the USA. The survey - translated into Spanish - was distributed by mail and completed by 136 retailers in Peru and 163 retailers in Argentina.

Findings - Links were assessed among strategic capabilities, generic business strategies, and performance in retail businesses in Argentina, Peru and the USA. Support was found for links between the focus strategy and both marketing and linking capabilities, between the differentiation strategy and technology capabilities, and between the cost leadership strategy and management capabilities. The low cost-differentiation combination strategy was associated with high performance in strategic groups whose businesses possess strong management and technology capabilities. These findings highlight the importance of developing strategy-specific capabilities as a foundation for superior performance.
\end{abstract}

Research limitations/implications - This study relied on self-reported assessments of competitive strategy, organizational capabilities, and performance. It utilized cluster analysis, assessed only retailers, and considered only three nations.

Originality/value - Extant strategic group research highlights the link between group membership and firm performance. The present study reinforces previous research. In addition, the presence of organization-specific strategic capabilities helps to explain why some businesses outperform others in the same strategic group.

Keywords Strategic groups, Competitive strategy, Spain, Argentina, Peru, United States of America Paper type Research paper

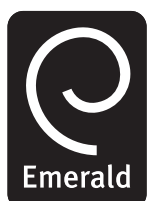

Management Decision Vol. 49 No. 1, 2011 pp. $130-155$ (C) Emerald Group Publishing Limited 0025-1747

DOI $10.1108 / 00251741111094482$
The generic strategy-business performance linkage has been widely documented over the past three decades (Capps et al., 2002; Moore, 2005; Mauri and Michaels, 1998; Parnell, 1997; Phelan et al., 2002). More recently, scholars have emphasized the organizational unit of analysis, including a prospective moderating role played by strategic capabilities (Bowman and Ambrosini, 2003; Campbell-Hunt, 2000; Hoque, 2004; Hussey, 2002; Lawless et al., 1989; Lopez, 2005; Pandza and Thorpe, 2009). Published work examining the influence of both business strategies and capabilities on performance in emerging economies is limited, however. Substantial research opportunities exist in this arena. 
This paper assesses the influence of strategic capabilities on the generic strategy-performance relationship among retail businesses in Argentina, Peru, and the USA. Specifically, do strategic capabilities in the realms of marketing, technology, market linking and/or management improve the prospects for superior performance among retailers employing cost leadership, differentiation, and focus strategies? If so, are linkages between capabilities and generic strategies similar among developed and emerging economies in the USA and Latin America?

The remainder of the paper is organized into several parts. An historical overview of literature relevant to generic strategies and capabilities is provided first. Next, the business environments of two emerging nations included in the present study Argentina and Peru - are presented. Hypotheses, methods, and findings follow, and results are probed further in a discussion section. The paper closes with conclusions, limitations, and future research opportunities.

\section{Competitive strategies and strategic groups}

Strategic management as a field - including the assessment of competitive or business strategies - is rooted in industrial organization (IO) microeconomics. The IO perspective views profitability primarily as a function of industry structure. IO's structure-conduct-performance model is widely considered to be more appropriate for industries with uncomplicated group structures, high concentrations, and relatively homogeneous firms (Seth and Thomas, 1994). Many scholars have questioned IO's ability to explain large performance variances within a single industry. To fill this void, the strategic group level of analysis was proposed as a middle ground between the industry and firm levels of analysis (Hergert, 1983; Porter, 1981).

A competitive or business strategy outlines how a business unit competes within its industry (Parnell, 2008). Although each business employs its own unique competitive strategy, strategic group assessments identify clusters of businesses that seek to execute similar competitive strategies. The strategic group level of analysis has contributed much to what is currently known about business strategies and performance (Capps et al., 2002; Leask and Parker, 2007; Mauri and Michaels, 1998; Phelan et al., 2002). Comparing outcomes between and among groups can help elucidate the strategic characteristics associated with high performance in a given industry without overemphasizing the behavior of a single business unit. Most strategic group level research linking strategy and performance has investigated industries in the USA and other developed nations.

Business strategy typologies are frameworks that identify multiple generic competitive strategies available to business units. Typologies were developed and used as a theoretical basis for identifying strategic groups across industries (Zahra and Covin, 1993). Numerous generic strategy typologies have been proposed, with those developed by Porter $(1980,1985)$ and Miles and Snow $(1978,1986)$ receiving much early scholarly attention. Scholars have since proffered various competitive typologies, some distinctive and others building on previously developed frameworks (see Garrigos-Simon et al., 2005; Goh, 2006; Herbert and Deresky, 1987; Nwokah, 2008). Porter's and Miles and Snow's original typologies remain among the most widely cited, tested, criticized, and refined (Bantel and Osborn, 1995; Bowman, 2008; Eng, 1994; Veett et al., 2009). 
$\mathrm{MD}$

49,1

132
According to Porter's (1980) framework, a business can pursue superior performance by either establishing a cost leadership position or differentiating its products and services from those of its rivals. Either approach may be accompanied by focusing efforts on a given market niche. Porter (1980) emphasizes the necessity of strategic tradeoffs, suggesting that a business attempting to combine emphases on low costs and differentiation invariably finds itself "stuck in the middle" (p. 41), a notion that received considerable early support (Dess and Davis, 1984; Hawes and Crittendon, 1984).

Whereas Porter contends that the assumptions associated with cost leadership and differentiation are incompatible, those in the combination strategy school have argued that businesses successfully combining the two may create synergies that overcome any tradeoffs that may be associated with the combination (Chan and Wong, 1999; Hill, 1988; Murray, 1988; Parnell, 1997; Phillips et al., 1983; Wright, 1987). Proponents of the combination strategy approach base their arguments on both broad economic relationships and anecdotal evidence demonstrating how individual firms have identified such relationships unique to one or a small group of firms in an industry.

While early strategic group research emphasized performance implications of group membership, later work began to examine behavioral distinctions, using group membership to explain competitive positioning, strategic behaviors, and rivalry patterns. Whereas performance-based research starts with the industry and works downward toward strategic groups, behavior-based studies tend to start with the organization-level data and work upward toward the strategic groups (Thomas and Pollock, 1999; Tywoniak et al., 2007).

The overall contribution of strategic group research to the field of strategic management has been extensive and wide ranging, considering both domestic and global contexts (Garrigos-Simon et al., 2005; Jusoh and Parnell, 2008; Rugman and Verbeke, 2008; Spanos et al., 2004), as well as content and process dimensions (Richter and Schmidt, 2005; Sorge and Brussig, 2003; Varadarajan, 1999). A finding common to most published work is the notion that businesses lacking a coherent and consistent strategic orientation (i.e. "reactors" within the Miles and Snow framework or those "stuck in the middle" within Porter's conceptualization) tend to be outperformed by others in their respective industries. DeSarbo and Grewel (2008) proposed the notion of hybrid strategic groups composed of businesses that combine strategic recipes from more than one pure group. Their conceptualization reinforces the strategic group concept, while allowing for groups of businesses pursuing various combination strategies.

As with all levels of analysis, strategic group research has its shortcomings. The existence of strategic groups - in general or in specific industries - has been challenged on both conceptual and empirical grounds (Barney and Hoskisson, 1990). Dranove et al. (1998) argued that strategic groups exist in a given industry if group effects on firm performance can be separated from organization and industry effects.

In a similar vein, the notion of strategic groups assumes not only the existence of groups of businesses employing similar competitive strategies but also the existence of clear and recognizable industries. These assumptions might appear intuitive at first, but different industry conceptualizations can result in markedly different strategic groups because groups emphasize the relative strategic position of businesses in an industry. For example, fast-food restaurants might be considered as a cost leadership 
strategic group within the broader restaurant industry because they emphasize cost containment more than their fast casual and upscale competitors. If a narrow fast-food industry definition is invoked, however, some fast food establishments might still be considered as low cost leaders while others are more closely aligned with differentiation.

\section{The resource-based view and strategic capabilities}

Concerns about these shortcomings and a general frustration with IO's deterministic underpinnings of the strategic group approach sparked a transition away from the industry level of analysis (Barney, 1991; Collis and Montgomery, 2008; Grant, 1991). An alternative paradigm emphasized unique firm competencies and resources in strategy formulation instead of industry characteristics (Kim and Mahoney, 2005; Pitelis, 2004; Wernerfelt, 1984). Scholars invoking the resource-based view (RBV) have examined such issues as competitive imitation, informational asymmetries, causal ambiguities, and the resource accumulation process (Barney, 1986; Reed and DeFillippi, 1990). The nature of competitive advantage also enjoyed a renewed prominence within the RBV (Peteraf, 1993).

Accepting the transitory nature of resources that lead to competitive advantage is a key concern for the RBV (Dess et al., 1995; Feurer and Chaharbaghi, 1994; Robins and Wiersema, 1995; Sheehan and Foss, 2007). The increasing pace of change and the notion of ephemeral competitive advantage have led to the development of dynamic strategy positioning models (Chung et al., 2006). Such models do not refute the tenets of $\mathrm{IO}$, organizational economics, or the RBV, but challenge static assumptions in favor of more flexible and adaptive approaches, especially where success depends on a constant flow of new offerings (Barnett, 2006; Feigenbaum and Thomas, 2004; Selsky et al., 2007).

The RBV embraces a firm level of analysis, but does not completely depart from IO assumptions (Barney and Ouchi, 1986). Although the two approaches may be viewed as compatible in some respects, conflicts between IO and the RBV ultimately concern the relative influence of industry and firm factors on business performance. Several studies have shed light on this conundrum. McGahan and Porter (1997) found that industry factors accounted for 19 percent of the variance in profitability within specific industry categories, and that the difference varied substantially across industries. Powell (1996) suggested that industry factors account for between 17 and 20 percent of variance in firm performance. Short and et al.'s (2007) assessment of firms in 12 industries suggested that firm-level effects on performance are generally the strongest, but that strategic group and industry effects are also significant.

Henderson and Mitchell (1997) noted that resolving the firm-industry conflict might not be possible because organizational capabilities, competition, strategy, and performance are fundamentally endogenous. Any attempt to build on the merits of both the IO and resource-based perspectives must account for the varying degrees of influence of both industry factors and firm resources on performance (Claver-Cortes et al., 2004; Roquebert et al., 1996; Spanos et al., 2004). Toward this goal, a renewed interest in organizational economics emerged in the 2000s, encompassing issues such as incentives, agency theory, transactions cost theory, authority and delegation, decentralization, and property rights theory, has built on both IO and the RBV

\section{Retailers in Argentina, Peru and the USA}


$\mathrm{MD}$

49,1

134

(Fulghieri and Hodrick, 2006; Foss and Foss, 2005; Gibbons, 2003; Kim and Mahoney, 2005; Sheehan and Foss, 2007; Tywoniak et al., 2007; Whinston, 2003).

The notion of strategic capabilities represents a key component of this resurgence (DeSarbo et al., 2005). An organization's resources - including its assets and skills represent the source of its foundation for sustainable competitive advantage (Aaker, 1989; Atoche, 2007; Bowman and Ambrosini, 2003). Strategists should seek to shape, transform, and combine these resources into strategic capabilities, which in term drive strategic success (Hussey, 2002; Lopez, 2005; Pandza and Thorpe, 2009).

The notion of strategic capabilities is conceptually linked to the RBV, as both perspectives emphasize the development of idiosyncratic aptitudes that cannot be readily mimicked by competitors. Scholars following the dynamic resource based view (DRBV) or dynamic capabilities approach (DCA) view resources as transitory, typically following a lifecycle behavior spanning emergence through various stages including growth, renewal, and eventual retirement (Helfat and Peteraf, 2003). Scholars from the organizational economics perspective - integrating perspectives such as agency theory, incentives, transaction costs theory, and even property rights theory have utilized IO-based tools to examine performance at the firm level of analysis (Boxall and Gilbert, 2007; Fulghieri and Hodrick, 2006; Foss and Foss, 2005; Gibbons, 2003; Whinston, 2003). Following the same conceptual foundation, the DCA extends strategic capabilities by emphasizing the transitory nature of both organizational resources and external influences (Ambrosini and Bowman, 2009; Augier and Teece, 2009; McGuinness and Morgan, 2000).

\section{Argentina and Peru}

The present study seeks to gain insight into linkages between generic strategy, strategic capabilities, and performance in both developed and developing nations. Toward this end, two countries in South America - Argentina and Peru - were selected for investigation. These two nations are often referenced as part of a larger, emerging Latin American cluster. Although published work has addressed general management tendencies in Argentina and Peru (Miozzo and Grimshaw, 2008; Sully de Luque and Arbazia, 2005), studies linking generic strategic or strategic capabilities with performance remain limited (Atoche, 2007).

Management practice in Latin America is quite intriguing. The pace of business is much slower in this part of the world, with more top-down decision-making than one might see in the USA or Western Europe. Roman Catholicism is dominant throughout the region and can be seen through a strong family orientation in the workplace (Kumar and Chase, 2006). Argentine and Peruvian managers have been moving toward greater interaction, more decentralized decision-making, and more participative leadership styles, although the current strength of this shift remains unclear (Buchenrieder and Heuft, 2003; Davila and Elvìra, 2007; Galbraith and Nkwenti-Zamcho, 2005; Kumar and Chase, 2006; Sully de Luque and Arbazia, 2005).

Both nations have a history of strong political leadership, a tradition consistent with the general preference in Latin-American nations for a charismatic leadership style. Managers tend to possess a greater tolerance for role ambiguity than their counterparts in the USA. Although Argentine and Peruvian managers have become more open to 
participative management styles, such approaches are not nearly as prominent as in the USA (D'Andrea et al., 2006; Maharajh and Heitmeyer, 2005; Weyzig, 2006).

Cultural similarities notwithstanding, there are significant ancestral differences between the two nations. About 45 percent of Peruvians are Amerindians, followed by 37 percent mestizos and 15 percent whites. While 87 percent of Argentines claim European descent, 8 percent are mestizos, tracing their ancestry to both Europeans and Amerindians. Cultural, structural, and economic differences also exist between Argentina and Peru (Husted and Allen, 2006; Lenartowicz and Johnson, 2003). Some of the key distinctions are difficult to assess because of considerable differences across subgroups within each nation. These differences exist throughout Peru, particularly when one compares Lima to the smaller, more isolated communities in outlying areas. Management tendencies are difficult to encapsulate there because of substantial differences across geographical regions, firms and industries (Bieber and Mukhtyar, 1999; Jackle and Li, 2006).

Peru's economy is comprised of modern and subsistence sectors, with the former most prominent in the capital, Lima. The proportion of women in Lima's work force grew from about one-third in 1970 to one-half by 2000 (Lazo, 1994; Sully de Luque and Arbazia, 2005). Historically, working conditions in Peru have been challenging and even abusive (Kay, 1997; Palmer, 1992; Parodi, 2000). Economic progress throughout the last 50 years has been sporadic in both nations, although the highs and lows have been most pronounced in Argentina (Carrera et al., 2003).

Management practice is difficult to encapsulate in both nations because of substantial differences across firms and industries. A key challenge in assessing Peruvian organizations is that fact that formal human resource practices became prevalent only in the last decade and are mostly seen in Lima's large organizations (Sully de Luque and Arbazia, 2005). Most organizations in Lima are small, however, and they are managed much differently from their larger counterparts.

Key variations exist in the retail environments across the three nations, the most prominent of which can be seen from a developmental perspective. Retail markets in Argentina and Peru are not as developed and sophisticated as those in the USA (Jackle and Li, 2006; Sully de Luque and Arbazia, 2005). Although none of the hypotheses address differences across borders, the issue of national distinctions is considered in the discussion section.

\section{Hypotheses}

The present study seeks to expand our understanding of the strategy-performance relationship by drawing from both strategic group and strategic capability research streams. Toward this end, five hypotheses are proposed and tested, and summarized in Figure 1.

Numerous studies have linked each of Porter's generic strategy approaches differentiation, cost leadership, and focus - to performance. Most published work has been in the developed world, but a number of studies in emerging nations have supported the validity of Porter's approach (Jusho and Parnell, 2008). Ceteris paribus, one would expect a positive association between each of these strategies and organizational performance in both the USA and the emerging economies of Argentina and Peru (Parnell, 1997, Wright, 1987). A general association between business

\section{Retailers in Argentina, Peru and the USA}

135 
$\mathrm{MD}$

49,1

136

Figure 1.

Proposed strategy-

capabilities-performance linkages

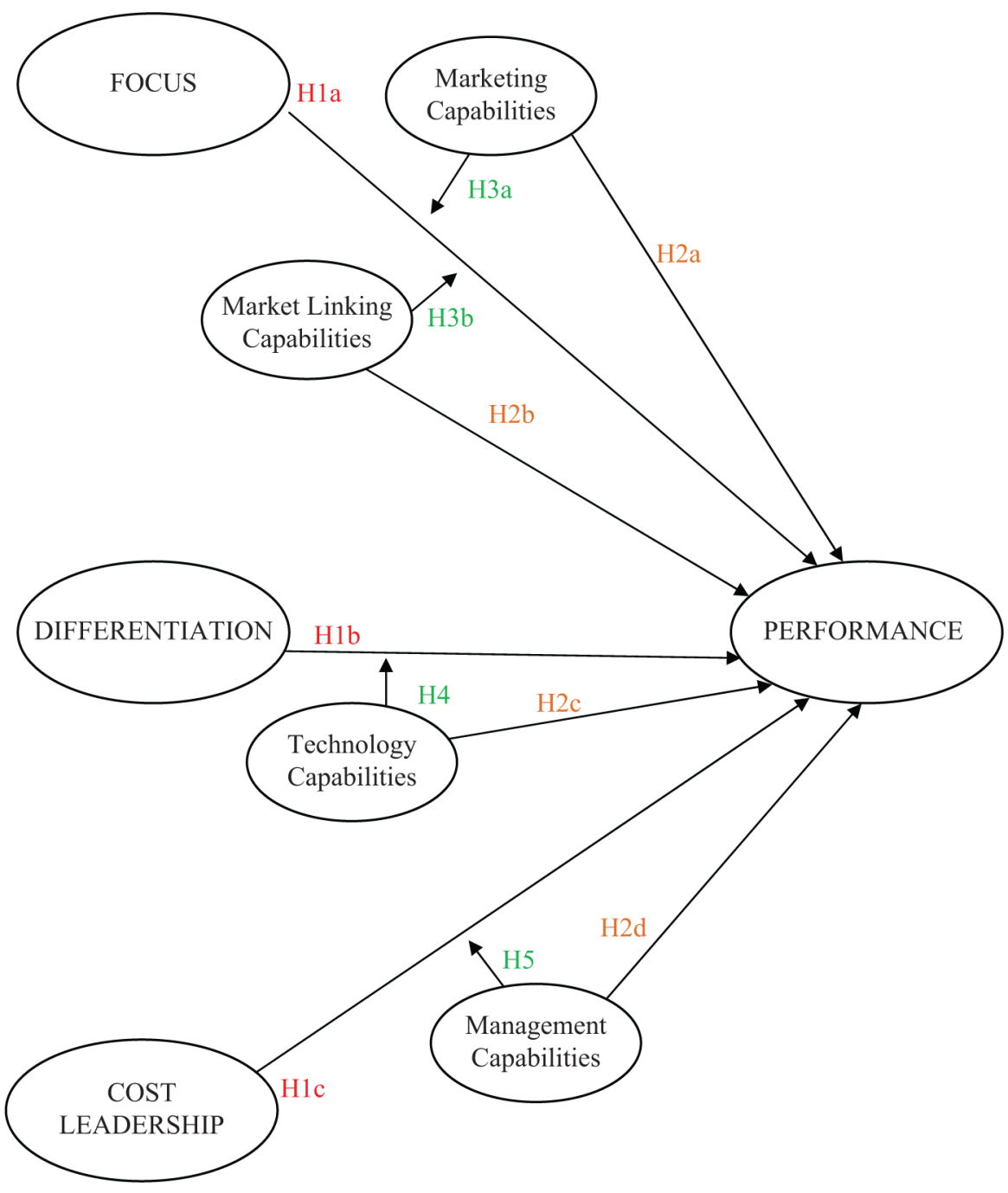

strategy emphasis and performance would serve as a foundation for testing the remaining hypotheses.

H1. There is a positive and significant association between each of Porter's strategic emphases (H1a) cost leadership (H1b) differentiation, and (H1c) focus - and organizational performance.

Regardless of generic strategy, the development of various strategic capabilities is also believed to have a positive influence on business performance in all three nations (DeSarbo et al., 2005; Pandza and Thorpe, 2009). As with the previous hypothesis, a general link between capabilities and performance would inform the testing of the remaining hypotheses linking strategies and capabilities. 
H2. There is a positive and significant association between each of DeSarbo's strategic capabilities $(H 2 a)$ marketing $(H 2 b)$ market linking $(H 2 c)$ technology, and $(H 2 d)$ management - and organizational performance.

Conventional wisdom and previous research suggests that strategists should translate resources into strategic capabilities that serve as a foundation of business strategies and ultimately drive strategic success (Campbell-Hunt, 2000; Hussey, 2002; Lawless et al., 1989; Lopez, 2005; Pandza and Thorpe, 2009). More specifically, certain strategic capabilities are likely to be more important to businesses employing certain strategies (Ambrosini and Bowman, 2009). For example, Porter's focus strategy is based on the idea that concentrating efforts on a particular market niche can lead to superior performance. Following this logic, one would expect that capabilities in the realms of marketing and market linking serve as a necessary precursor to the execution of a focus strategy (Collis and Montgomery, 2008; Jusoh and Parnell, 2008).

H3. Successful businesses emphasizing a focus orientation will report high strategic capability levels in the areas of $(H 3 a)$ marketing and $(H 3 b)$ market linking.

Porter's differentiation approach is often built on technological leadership. Hence, it is expected that high performing differentiated businesses are more likely to possess technological expertise than their counterparts pursuing other strategies (Porter, 1980; Hill, 1988; Furrer et al., 2008). This relationship is also expected in Argentina and Peru (Garrigos-Simon et al., 2005; Rugman and Verbeke, 2008).

H4. Successful businesses emphasizing a differentiation orientation will report high strategic capability levels in the area of technology.

Porter's cost leadership approach emphasizes production efficiencies, and is likely to be linked to the development of management capabilities in high performing organizations (Porter, 1980; Veett et al., 2009). This relationship is also expected in Argentina and Peru (Jusoh and Parnell, 2008; Spanos et al., 2004).

H5. Successful businesses emphasizing a cost leadership orientation will report high strategic capability levels in the area of management.

\section{Methods}

Operationalizing Porter's business strategy typology was a key challenge, and several solutions were considered. Scholars can utilize objective indicators and infer a strategy from accounting data, base their strategy assessments on manager surveys, or consider a wide range of data and render an expert assessment (Golden, 1992; Parnell et al., 2006). Each approach has its shortcomings (Venkatraman and Ramanujam, 1986). In the present study, Zahra and Covin's (1993) self-reported scale was utilized to categorize businesses along Porter's typology. Several minor amendments suggested by Luo and Zhao (2004) were adopted, but the scale remained largely unchanged.

The measurement of organizational capabilities was also an important consideration. Strategic capability scales were adopted from DeSarbo et al. (2005). Their marketing capabilities scale was based on the work of Conant et al. (1990). Their market linking capabilities and technology capabilities scales were based on Day's

\section{Retailers in Argentina, Peru and the USA}

137 
$\mathrm{MD}$

49,1

138
(1994) previous work. DeSarbo et al. (2005) developed and validated a management capabilities scale, which has been employed as well.

Several options were considered regarding the measurement of organizational performance. Studies have demonstrated that what constitutes an effective strategy can depend on how effectiveness is measured (Atkinson, 2006; Cavalieri et al., 2007; Dye, 2004; Jusoh and Parnell, 2008; Pongatichat and Johnston, 2008; Ramanujam and Venkatraman, 1987; Venkatraman and Ramanujam, 1986). Early studies focused on financial measures of performance, but there is a growing consensus that a broader conceptualization of performance should be invoked (Hillman and Keim, 2001; Kaplan and Norton, 1997; Laitinen, 2002). Specifics surrounding the measurement of organizational performance are widely debated, and some scholars have suggested that different measures are appropriate for different strategies (Dye, 2004; Van der Stede et al., 2006).

Qualitative measures have been emphasized in a number of studies and include subjective areas of performance such as the satisfaction of managers, customers and other stakeholders, and even ethical behavior. Viewing performance through a qualitative lens can provide insight into organizational processes and outcomes that cannot be seen via financial measures (Ayadi et al., 1996; Huselid, 1995; Parnell et al., 2006). As such, self-reporting scales to assess relative competitive and objective performance in the present study were adopted from Ramanujam and Venkatraman (1987). Items contained in the strategy, capabilities, and performance scales are elaborated in the Appendix.

In the USA, the survey was administered to attendees at a national retail trade show in Chicago, 87 percent of who held management positions in the industry. A total of 277 responses were received. All three management levels were represented in the sample, with slightly more women participating than men. Businesses of various sizes were represented in the sample, as depicted in Table I.

Surveys were translated into Spanish and distributed by mail to the 574 retailers in Peru listed in the Selectory.com directory. From this group, 136 responses were received, for a response rate of 23.7 percent. Surveys were distributed by mail to a random group of 600 retailers in Argentina listed in the Selectory.com directory. From this group, 163 responses were received, for a response rate of 27.2 percent. The

\begin{tabular}{|c|c|c|c|c|c|c|}
\hline \multirow[b]{2}{*}{ Variable } & \multicolumn{2}{|c|}{ Argentina } & \multicolumn{2}{|c|}{ Peru } & \multicolumn{2}{|l|}{ The USA } \\
\hline & $(n=163)$ & $(\%)$ & $(n=136)$ & $(\%)$ & $(n=277)$ & $(\%)$ \\
\hline Management experience (years) & 5.47 & & 2.48 & & 3.72 & \\
\hline Organization experience (years) & 5.74 & & 3.81 & & 4.75 & \\
\hline Number of employees & 516 & & 284 & & 2,529 & \\
\hline Annual revenues $(\$ 000)$ & $\$ 48,216$ & & $\$ 14,431$ & & $\$ 225,377$ & \\
\hline \multicolumn{7}{|l|}{ Sex } \\
\hline Male & 88 & 54 & 76 & 56 & 117 & 42 \\
\hline Female & 75 & 46 & 60 & 44 & 160 & 58 \\
\hline \multicolumn{7}{|l|}{ Level } \\
\hline Non-management & 12 & 7 & 20 & 15 & 35 & 13 \\
\hline Lower & 46 & 28 & 37 & 27 & 79 & 29 \\
\hline Middle & 75 & 46 & 67 & 49 & 109 & 39 \\
\hline Upper & 30 & 18 & 12 & 9 & 54 & 19 \\
\hline
\end{tabular}

Table I.

Sample characteristics 
majority of surveys mailed to Peruvian retailers were sent to Lima, whereas those sent to Argentine retailers were more geographically dispersed throughout the country. Data from all three nations was collected in 2009.

Cluster analysis has been a prominent tool of strategic group researchers for classifying businesses into strategic groups, especially in early studies (Cool and Schendel, 1988; Derajtys et al., 1993), most of which suggested a link between strategic group membership and performance (Dess and Davis, 1984; Katobe and Duhan, 1993). Cluster algorithms have been challenged on empirical grounds, however (Ketchen and Shook, 1996; Thomas and Venkatraman, 1988). Cluster analysis identifies groups whether or not they actually exist in a particular industry (Barney and Hoskisson, 1990; Hatten and Schendel, 1977), so theoretical justification of the groups is paramount. Cluster analysis is an attractive approach because it enables strategic group formation along identified variables, but does not necessarily force group membership along predetermined conceptualizations. This is a key advantage when the technique is applied to diverse cultures, because the grouping variables are allowed to coalesce in different ways in each sample.

Cluster analysis was utilized to identify strategic groups in each of the three nations of interest. The optimal number of groups was the largest one whereby no two groups shared a similar strategic orientation. Ward's algorithm was employed because of its proclivity for identifying groups of similar sizes.

\section{Findings}

Each of the strategy and capabilities scales was factor analyzed to assess reliability before hypotheses were tested. Data from each country were analyzed individually to identify differences that might exist across nations. Factor loadings and coefficient alphas for the strategy and performance scales appear in Table II. Those for the capabilities scales appear in Table III. Reliability scores were strong, with all of them above 0.600 and only two (0.624 and 0.642$)$ below 0.700 .

Factor scores (regression method) were computed to serve as surrogate measures along the strategy and capability dimensions for each organization in the sample. A factor score of zero represents an overall value at the industry mean, whereas positive and negative scores reflect higher and lower values based on the number of standard deviations

The first hypothesis was partially supported. Correlations between factor scores for each of the three strategies and performance was positive and significant in the USA (see Table IV). The links between cost leadership and performance in Argentina, and between focus and performance in Peru were also positive and significant. The remaining correlations were also positive, but not significant.

The second hypothesis was partially supported. Correlations between factor scores for each of the four capabilities and performance was positive and significant in the USA and Peru (see Table V). The links between marketing and performance and between linking and performance were significant and positive in Argentina. The links between technology and performance and between management and performance were also positive, but not significant.

Because the precise definition of strategic groups can vary across industries and nations, the remaining hypotheses were evaluated by examining the cluster results. A cluster analysis of businesses in each nation along Porter's three strategy 


\begin{tabular}{|c|c|c|c|c|}
\hline & & & & \\
\hline 49 & Scale & Argentina $(n=163)$ & Peru $(n=123)$ & The USA $(n=277)$ \\
\hline & Cost leadership & Alpha $=0.707$ & Alpha $=0.624$ & Alpha $=0.733$ \\
\hline & Cost1 & 0.706 & 0.548 & 0.640 \\
\hline & Cost2 & 0.697 & 0.682 & 0.660 \\
\hline & Cost3 & 0.707 & 0.733 & 0.693 \\
\hline 140 & Cost4 & 0.739 & 0.807 & 0.700 \\
\hline & Cost5 & 0.552 & 0.365 & 0.779 \\
\hline & Focus & Alpha $=0.642$ & Alpha $=0.681$ & Alpha $=0.788$ \\
\hline & Focus1 & 0.610 & 0.649 & 0.730 \\
\hline & Focus2 & 0.678 & 0.636 & 0.695 \\
\hline & Focus3 & 0.784 & 0.762 & 0.836 \\
\hline & Focus4 & 0.710 & 0.810 & 0.864 \\
\hline & Differentiation & Alpha $=0.780$ & Alpha $=0.770$ & Alpha $=0.854$ \\
\hline & Differ1 & 0.556 & 0.523 & 0.721 \\
\hline & Differ2 & 0.671 & 0.635 & 0.779 \\
\hline & Differ3 & 0.768 & 0.715 & 0.762 \\
\hline & Differ4 & 0.754 & 0.799 & 0.855 \\
\hline & Differ5 & 0.541 & 0.466 & 0.675 \\
\hline & Differ6 & 0.702 & 0.777 & 0.678 \\
\hline & Differ7 & 0.616 & 0.681 & 0.673 \\
\hline & Performance & Alpha $=0.899$ & Alpha $=0.910$ & Alpha $=0.927$ \\
\hline & SalesROA & 0.765 & 0.807 & 0.852 \\
\hline & ProfitROA & 0.735 & 0.826 & 0.574 \\
\hline & MktShare & 0.739 & 0.692 & 0.864 \\
\hline & ROA & 0.745 & 0.807 & 0.683 \\
\hline Table II. & ROE & 0.786 & 0.822 & 0.845 \\
\hline Factor analyses of & ROS & 0.798 & 0.787 & 0.890 \\
\hline strategy and performance & Overall & 0.751 & 0.766 & 0.879 \\
\hline scales & CompPos & 0.819 & 0.782 & 0.879 \\
\hline
\end{tabular}

dimensions - cost leadership, differentiation, and focus - generated nine clusters in the USA, and five in both Argentina and Peru. Results appear in Table V. In each nation, one cluster of businesses consisted of low factor scores along each strategy, capability and performance. The remaining clusters encompassed various combinations of strategy and capability scores.

$\mathrm{H} 3 \mathrm{a}$ and $\mathrm{H} 3 \mathrm{~b}$ were largely supported, but an analysis by nation is warranted. Two Argentine clusters emphasized a focus orientation. The fourth cluster scored high on all three strategies, $0.84,0.87$, and 0.92 on cost, focus, and differentiation respectively. Capability and performance scores were also above the median, making conclusions difficult to assess. The fifth cluster, however, scored the highest on the focus strategy $(0.94)$ and was also low on differentiation $(-0.60)$. Businesses in this cluster reported low marketing capability levels $(-0.46)$. Linking capability $(0.09)$ and performance $(0.08)$ were close to the norm. For these businesses, a strong focus orientation was not supported by marketing and linking capabilities, and was not associated with high performance. Hence, the Argentine clusters provide limited support.

Like Argentina, two Peruvian clusters emphasized a focus orientation. The first cluster scored high on all three strategies $(0.73,0.99$, and 1.13$)$, but scores for all four capability levels, and performance were near the mean. The strong strategic orientation in all three areas was not supported by strategic capabilities and did not 


\begin{tabular}{|c|c|c|c|c|}
\hline Scale & Argentina $(n=163)$ & Peru $(n=123)$ & The USA $(n=277)$ & Argentina Peru \\
\hline Marketing & Alpha $=0.799$ & Alpha $=0.766$ & Alpha $=0.935$ & and the USA \\
\hline Cap-Mkt1 & 0.618 & 0.707 & 0.875 & IU IIIC UNA \\
\hline Cap-Mkt2 & 0.671 & 0.759 & 0.885 & \\
\hline Cap-Mkt3 & 0.787 & 0.649 & 0.842 & \\
\hline Cap-Mkt4 & 0.750 & 0.714 & 0.877 & 141 \\
\hline Cap-Mkt5 & 0.693 & 0.547 & 0.885 & \\
\hline Cap-Mkt6 & 0.718 & 0.690 & 0.851 & \\
\hline Linking & Alpha $=0.819$ & Alpha $=0.771$ & Alpha $=0.894$ & \\
\hline Cap-Link1 & 0.699 & 0.658 & 0.769 & \\
\hline Cap-Link2 & 0.725 & 0.705 & 0.837 & \\
\hline Cap-Link3 & 0.632 & 0.622 & 0.782 & \\
\hline Cap-Link4 & 0.724 & 0.760 & 0.794 & \\
\hline Cap-Link5 & 0.814 & 0.748 & 0.809 & \\
\hline Cap-Link6 & 0.763 & 0.621 & 0.864 & \\
\hline Technology & Alpha $=.769$ & Alpha $=0.837$ & Alpha $=0.932$ & \\
\hline Cap-Tech1 & 0.765 & 0.755 & 0.882 & \\
\hline Cap-Tech2 & 0.788 & 0.824 & 0.847 & \\
\hline Cap-Tech3 & 0.809 & 0.734 & 0.850 & \\
\hline Cap-Tech4 & 0.760 & 0.648 & 0.861 & \\
\hline Cap-Tech5 & 0.815 & 0.838 & 0.866 & \\
\hline Cap-Tech6 & 0.754 & 0.667 & 0.878 & \\
\hline Management & Alpha $=0.769$ & Alpha $=0.826$ & Alpha $=0.889$ & \\
\hline Cap-Mgt1 & 0.693 & 0.736 & 0.791 & \\
\hline Cap-Mgt2 & 0.690 & 0.812 & 0.818 & \\
\hline Cap-Mgt3 & 0.741 & 0.809 & 0.853 & \\
\hline Cap-Mgt4 & 0.643 & 0.687 & 0.813 & Table III. \\
\hline Cap-Mgt5 & 0.715 & 0.736 & 0.816 & Factor analyses of \\
\hline Cap-Mgt6 & 0.610 & 0.610 & 0.722 & capability scales \\
\hline
\end{tabular}

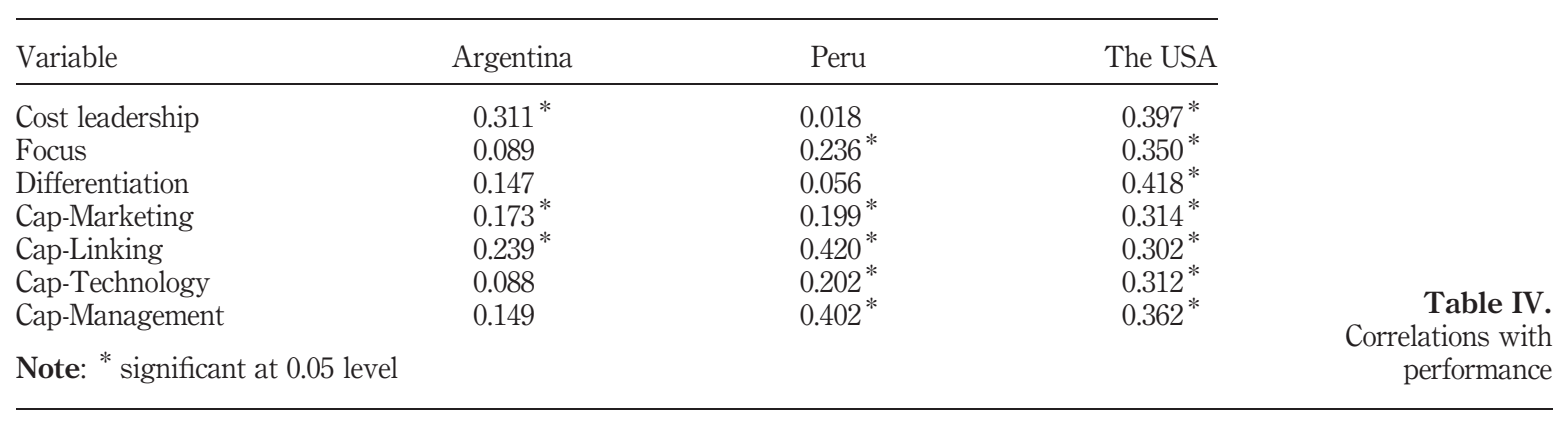

translate into high performance. The fifth cluster scored high along the focus dimension (0.76), supported by marketing (0.36) and linking (0.61) capabilities. Performance for this cluster was one-half of one standard deviation above the mean for the industry. Hence, the Peruvian clusters provide strong support.

In the USA, three clusters scored high on the focus strategy. The third cluster was the most focus-oriented (0.97). Marketing (0.08) and linking (0.18) capabilities were slightly above the mean, as was performance (0.13). The eighth cluster scored high on 


\begin{tabular}{|c|c|c|c|c|c|c|c|c|c|c|}
\hline \multirow{3}{*}{$\begin{array}{l}\mathrm{MD} \\
49,1\end{array}$} & \\
\hline & \multirow[b]{2}{*}{ Number } & \multirow[b]{2}{*}{ Description } & \multicolumn{3}{|c|}{ Generic strategies } & \multirow[b]{2}{*}{ Perf } & \multicolumn{4}{|c|}{ Strategic capabilities } \\
\hline & & & Cost & Focus & Diff & & Mktg & Link & Tech & Mgt \\
\hline \multirow{5}{*}{142} & \multicolumn{10}{|l|}{ Argentina } \\
\hline & 1 & No strategy $(n=34)$ & -0.98 & -0.80 & -1.33 & -0.50 & -0.40 & -0.24 & -0.37 & -0.51 \\
\hline & 2 & Cost leadership $(n=48)$ & 0.27 & -0.70 & 0.07 & 0.27 & -0.10 & 0.23 & 0.06 & 0.22 \\
\hline & 3 & Differentiation $(n=15)$ & -1.29 & 0.12 & 0.80 & -0.39 & 0.62 & -0.41 & -0.57 & -0.19 \\
\hline & 4 & Cost/differ/foc $(n=46)$ & 0.84 & 0.87 & 0.92 & 0.18 & 0.39 & 0.04 & 0.49 & 0.29 \\
\hline & \multicolumn{10}{|c|}{ 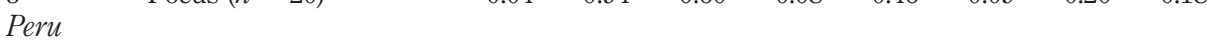 } \\
\hline & 1 & Cost/differ/foc $(n=30)$ & 0.73 & 0.99 & 1.13 & -0.01 & 0.02 & -0.11 & -0.13 & -0.13 \\
\hline & 2 & Cost/differ $(n=23)$ & 0.48 & -0.83 & 0.89 & -0.46 & 0.29 & 0.13 & 0.04 & -0.12 \\
\hline & 3 & No strategy $(n=23)$ & -1.68 & -0.52 & -0.98 & -0.45 & -0.29 & -0.80 & -0.50 & -0.78 \\
\hline & 4 & Cost leadership $(n=28)$ & 0.23 & -0.82 & -0.61 & 0.17 & -0.44 & -0.01 & 0.17 & 0.61 \\
\hline & 5 & Focus $(n=32)$ & -0.02 & 0.76 & -0.47 & 0.50 & 0.36 & 0.61 & 0.31 & 0.23 \\
\hline & \multicolumn{10}{|c|}{ The USA } \\
\hline & 1 & No strategy $(n=48)$ & -1.14 & -1.21 & -1.23 & -1.17 & -0.50 & -0.38 & -0.15 & -0.78 \\
\hline & 2 & Cost leadership $(n=28)$ & 0.61 & -1.09 & -0.84 & -0.55 & 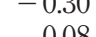 & 0.21 & -0.32 & 0.11 \\
\hline & 4 & Cost/focus $(n=35)$ & $\begin{array}{r}-0.10 \\
0.45\end{array}$ & 0.90 & -0.18 & 0.11 & 0.00 & 0.14 & $\begin{array}{l}-0.35 \\
-0.30\end{array}$ & 0.17 \\
\hline & 5 & Balanced $(n=31)$ & -0.12 & -0.20 & -0.18 & 0.39 & 0.04 & -0.17 & 0.13 & 0.19 \\
\hline Table V. & 6 & Differentiation $(n=22)$ & -1.22 & 0.03 & 0.58 & 0.30 & 0.61 & 0.10 & 0.73 & -0.01 \\
\hline Strategy cluster & 7 & Cost/differ $(n=14)$ & 1.30 & -1.14 & 0.75 & 0.54 & 0.02 & 0.05 & 0.24 & 1.09 \\
\hline Argentina, Peru, and the & 8 & Cost/differ/foc $(n=48)$ & 1.19 & 0.66 & 0.96 & 0.61 & 0.45 & 0.23 & 0.31 & 0.16 \\
\hline USA & 9 & Focus/differ $(n=26)$ & -0.13 & 0.94 & 1.55 & -0.19 & -0.22 & -0.23 & -0.14 & 0.17 \\
\hline
\end{tabular}

all strategies and capabilities, and performance, rendering conclusions difficult to assess. The ninth cluster scored high on focus (0.94) and differentiation (1.55). Support from marketing $(-0.22)$ and linking $(-0.23)$ capabilities was lacking, and performance was below the mean $(-0.19)$. Hence, the third and eighth US clusters provide support for the hypothesis.

The fourth hypothesis was largely supported. The third Argentine cluster scored high on differentiation (0.80) and was worthy of assessment. Businesses in this cluster were not supported by technology capabilities $(-0.57)$ and performance was low (-0.39). Overall, the Argentine clusters provide support for the hypothesis.

The aforementioned first Peruvian cluster scored high on all three strategies $(0.73$, 0.99, and 1.13), but scores for all four capability levels and performance were close to the mean. The strong strategic orientation in cost, focus, and differentiation was not supported by strategic capabilities and was not associated with high performance. The second Peruvian cluster scored high on cost (0.48) and differentiation (0.89). Scores for the technology capability were near the mean (0.04) and performance was low $(-0.46)$. Overall, the Peruvian clusters support the hypothesis, although results are not as strong as in Argentina.

Three US clusters are worthy of analysis. The sixth cluster scored high on differentiation (0.58). Supported by technology capabilities (0.73), performance in the cluster was somewhat higher than the mean (0.30). The seventh cluster scored high on both cost leadership (1.30) and differentiation (0.75). Technology capabilities were above the mean (0.24), and performance was strong (0.54). The ninth cluster scored 
high on focus (0.94) and differentiation (1.55). Technology capability was below the mean $(-0.14)$, as was performance $(-0.19)$. Overall, the US data supports the hypothesis.

The fifth hypothesis was largely supported. In Argentina, the second cluster was worthy of analysis. Emphasis on cost leadership was somewhat higher than the mean (0.27), as was the management capability score (0.22) and performance (027), lending support to the hypothesis.

In Peru, the second cluster scored high on cost (0.48) and differentiation (0.89). Scores for management capability were slightly below the mean $(-0.12)$ and performance was low $(-0.46)$. The fourth cluster was somewhat cost-oriented $(0.23)$. Management capability was high (0.61) and performance was above the mean (0.17). Overall, these clusters support the hypothesis.

In the USA, three clusters are worthy of assessment. The second cluster was cost-oriented, but management capability was near the mean $(0.11)$ and performance was low $(-0.55)$. The third cluster emphasized low costs $(0.45)$ and focus $(0.90)$. Management capability was slightly above the mean (0.17), as was performance (0.11). The seventh cluster emphasized cost leadership (1.30) and differentiation (0.75). Supported by strong management capability (1.09), performance was also high (0.54). Overall, data from the US sample lends support to the hypothesis.

\section{Discussion}

Support for the first and second hypotheses among retailers in the USA lends credence to the notion that emphasis on any strategy or development of any capability tends to positively influence performance. Similar relationships were found in Argentina and Peru, but the lack of significance in some instances suggests that the links are at least not as strong and may not be universal. It is also possible that such linkages are stronger in more developed markets. Nonetheless, the lack of any negative correlations - significant or not - reinforces the presumed positive influence of strategies and capabilities.

Support for the third, fourth, and fifth hypotheses, suggests that the strategy-performance relationship presumes the development of specific strategic capabilities associated with each strategy. The influence of national differences on the tests of $H 3, H 4$, and $H 5$ appear to be modest, although there are some interesting distinctions. Nine clusters were identified in the USA, but only five were identified in Argentina and Peru. Moreover, there were substantial conceptual similarities across four of the five clusters. Interestingly, clusters emphasizing differentiation were found in the USA and Argentina but not Peru, where differentiation was found only in clusters that also included an emphasis on cost leadership. This distinction might be attributable to Peru's status as an emerging nation. With cost and price as more prominent concerns among businesses and consumers, fewer retailers in Peru have the luxury of pure differentiation.

The strategic orientations identified vary somewhat across nations, so a second look at the clusters identified in each nation provides greater insight into the strategy-capability link. The retail environment in Argentina is fairly well developed by global standards, and more developed than that in Peru (Sully de Luque and Arbazia, 2005). In Argentina, the cost leadership cluster was supported by management capabilities and businesses in the cluster performed well overall. The 
$\mathrm{MD}$

49,1

144

differentiation cluster scored well in only one capability domain - marketing - and performance was low. Although marketing effectiveness can be important to any organization regardless of strategy, differentiated businesses in this cluster lacked critical technology capability to support execution. The low performance was as predicted.

The Peruvian retail environment in the least developed of the three and is heavily populated by very small and micro-enterprises (Jackle and Li, 2006; Sibeck and Stage, 2001). Although descriptive statistics (see Table I) suggest that these very small organizations were not well represented in the sample, they influence the competitive environment nonetheless. The first Peruvian cluster represents the classic low cost-differentiation combination strategy with focus, but a lack of strategic capabilities resulted in performance at the mean for the industry. The second cluster also represents a combination strategy but without focus. The only relatively high capability score in this cluster was marketing (0.29), a capability hypothesized to associate with a focus orientation. The other three capabilities would have been necessary to support the combination strategy, but each was close to the industry mean. Hence, the low performance was not a surprise.

In the USA, businesses in the cost leadership cluster reported management capability at the industry norm and performed poorly. Those in the cost-focus cluster reported marketing, linking, and management capabilities at or slightly above the industry mean and experienced performed slightly above the mean as well. The differentiation cluster was supported by strong technology capabilities and performed well. Businesses in the combination strategy cluster - unlike those in Peru - reported strong technology and management capabilities and performed well. Those in the focus-differentiation cluster lacked the requisite capabilities and performed below the industry mean.

The relationship between technology capabilities and differentiation is consistent with previous research. Innovativeness heterogeneity linked to technology has been noted in Mexico and Brazil (Dutrénit, 2000; Figueiredo, 2001; Dutrénit et al., 2003). This relationship is complex, however (Dutrénit, 2006).

\section{Conclusions, limitations, and future research}

Several key conclusions can be drawn from the findings presented herein. First, strategic capabilities and generic strategies were associated in all three nations. Hypothesized links were found in most but not all instances, although the capability-strategy relationship appears more intricate than can be fully elaborated with the present data. Specifically, the success of a given business strategy appears to be predicated on the development of one or more requisite strategic capabilities.

Second, the present study provides insight into the complexity of the combination strategy debate. The original debate focused on economic trade-offs associated with generic strategies, not idiosyncratic attributes of individual organizations that might facilitate or impede effective execution of two or more strategies simultaneously. Strategic capabilities represent a key organizational factor. In the present study, performance tended to be strong in instances where combination strategy clusters also scored high on the requisite strategic capabilities, but weak where such capabilities have not been developed. Hence, Porter's notion of combination strategy businesses as "stuck in the middle" seems to pertain to those organizations unable to develop the 
elusive combination of capabilities necessary to support such an approach. Those able to do so can perform well.

Third, this study can inform further work that integrates the strategic group and business levels of analysis (Campbell-Hunt, 2000). Organization-specific strategic capabilities appear to help explain why some businesses outperform others in the same strategic group. Further delineating this relationship will comprise a key contribution to the literature (Furrer et al., 2008).

This study not only informs scholars, but has two clear implications for practitioners as well. First and foremost, seeking to implement the "right strategy" perhaps a strategy that seems to be effective for one's rivals - is not advisable. Effective strategies are necessarily linked established strategic capabilities. The present study highlighted links between the focus strategy and both marketing and linking capabilities, between the differentiation strategy and technology capabilities, and between the cost leadership strategy and management capabilities. The low cost-differentiation combination strategy was associated with high performance in strategic groups whose businesses possess strong management and technology capabilities. Hence, understanding an organization's strategic capabilities vis-à-vis those possessed by key competitors is an important prerequisite to successful strategy formulation and execution.

Second, executives should understand the links between specific capabilities and strategy execution in their respective industries and economic environments. The present study examined retailers in three disparate nations. While some generalizability to other nations and industries is likely, key differences probably exist and the links may be fluid as well. Developing such an understanding is a key executive function, perhaps the one most critical to strategic success at the business level.

Several limitations of the present study should be noted, however. Only retailers in three nations were assessed, and differences in strategic orientation across nations suggest that results could be different in other countries. An assessment of other industries could also produce different results. Moreover, cluster analysis allows strategic groups to form around predetermined strategic orientations, but assumes the existence of those orientations. Other classification schemes could be utilized as well.

Innovation capability - the ability to create new and useful knowledge based on previous knowledge (Kim, 1997) - has been proposed as a higher order capability that integrates others developed by the firm (Atoche, 2007). Studies suggest innovation capabilities emerge from technology capabilities (Bell and Pavitt, 1992; Dutrénit, 2004; Figueiredo, 2001). Organizations in emerging economies often lack the technological base to develop innovation capabilities. The present study considered three primary strategic capabilities. Possibilities like innovation capability were not assessed.

There are numerous avenues for future research. First, with regard to Peru and Argentina, replications in other emerging countries may identify links common to developing nations. Additional work in this regard is essential to enhance the generalizability of findings presented in this study.

Second, methodological consistency in cross-national research is important, but problems arise when constructs and surveys are modified or translated to fit samples in other cultures (Parnell, 2008; Proff, 2002; Punnett and Shenkar, 1994; Sibeck and Stage, 2001). As such, some management constructs developed in advanced western nations may be inappropriate in emerging economies, and new culture-specific constructs may

\section{Retailers in Argentina, Peru and the USA}


$\mathrm{MD}$

49,1

146

more accurately explain management behavior. Modified research approaches that compare and contrast practices among widely divergent cultures without forcing one culture into the construct definition appropriate in another are also needed.

Third, the relationships among competitive strategy, strategic capabilities, and business performance appear to be quite complex. Moreover, there are valid debates about how each of these constructs can and should be measured, given the multitude of industry and cross-cultural differences that also exist, findings in the present study can only be considered preliminary. Research that builds on the conclusions presented herein is needed.

This additional work will not only foster theoretical development, can also address the gap between scholars and practitioners. Modeling the strategy-capabilityperformance nexus requires a keen understanding of industry factors. Practitioners can benefit immensely from this effort as they attempt to align strategies, capabilities, and environmental factors.

Finally, most competitive strategy studies have assessed the link between strategy and performance over a fixed, relatively short time frame. High performing businesses generate profits and other positive outcomes over an extended period of time. Following the DCA and DRBV research streams, market sustainability reflects the extent to which a strategy's success can achieve a desired level of financial performance while enduring current and potential change across competitors and markets (Boxall and Gilbert, 2007; Fulghieri and Hodrick, 2006; Gibbons, 2003; Helfat and Peteraf, 2003; Whinston, 2003). The extent to which sustainable competitive advantage is developed cannot be accurately assessed in a single iteration.

\section{References}

Aaker, D.A. (1989), "Managing assets and skills: the key to a sustainable competitive advantage", California Management Review, Vol. 31 No. 2, pp. 91-106.

Ambrosini, V. and Bowman, C. (2009), "What are dynamic capabilities and are they a useful construct in strategic management?", International Journal of Management Reviews, Vol. 11, pp. 29-49.

Atkinson, H. (2006), "Strategy implementation: a role for the balanced scorecard?", Management Decision, Vol. 44, pp. 1441-60.

Atoche, C. (2007), "Capability lifecycles: an insight from the innovation capability evolution in emerging economies", Cladea's Annual Assembly, Florida International University, Miami, FL.

Augier, M. and Teece, D. (2009), "Dynamic capabilities and the role of managers in business strategy and economic performance”, Organization Science, Vol. 20, pp. 410-21.

Ayadi, O.G., Dufrene, U.B. and Obi, C.P. (1996), "Firm performance measurement: temporal roadblock to innovation?”, Managerial Finance, Vol. 22, pp. 18-22.

Bantel, K.A. and Osborn, R.N. (1995), "The influence of performance, environment and size on the identifiability of firm strategy", British Journal of Management, Vol. 6, pp. 235-48.

Barnett, M.L. (2006), "Finding a working balance between competitive and communal strategies", Journal of Management Studies, Vol. 43, pp. 1753-73.

Barney, J.B. (1986), "Strategic factor markets: expectations, luck, and business strategy", Management Science, Vol. 32, pp. 1231-41.

Barney, J.B. (1991), "Firm resources and sustained competitive advantage", Journal of Management, Vol. 17, pp. 99-120. 
Barney, J.B. and Hoskisson, R.E. (1990), "Strategic groups: untested assertions and research proposals", Managerial and Decision Economics, Vol. 11, pp. 187-98.

Barney, J.B. and Ouchi, W.G. (1986), Organizational Economics, Jossey-Bass, San Francisco, CA. Bell, M. and Pavitt, K. (1992), “Accumulating technological capability in developing countries”, Proceedings of the World Bank Annual Conference on Development Economics, pp. 257-81.

Bieber, S.M. and Mukhtyar, M. (1999), "Crisis management”, Business Mexico., Vol. 8/9, p. 16.

Bowman, C. (2008), "Generic strategies: a substitute for thinking?”, Ashridge Journal, Spring, pp. 6-11.

Bowman, C. and Ambrosini, V. (2003), "How the resource-based view and the dynamic capability views of the firm inform corporate-level strategy", British Journal of Management, Vol. 14, pp. 289-303.

Boxall, P. and Gilbert, J. (2007), "The management of managers: a review and conceptual framework", International Journal of Management Reviews, Vol. 9 No. 2, pp. 95-115.

Buchenrieder, G. and Heuft, A. (2003), "Decentralization in Peru's agriculture policy: a critical review from 1993-1998”, Oxford Development Studies, Vol. 31, pp. 341-63.

Campbell-Hunt, C. (2000), "What have we learned about generic strategies? A meta-analysis", Strategic Management Journal, Vol. 21, pp. 127-54.

Capps, C.J. III, Jackson, G.K. and Hazen, S.E. (2002), "Strategic management synergy in the twenty-first century”, Journal of Applied Management and Entrepreneurship, Vol. 7 No. 1, pp. 76-93.

Carrera, A., Mesquita, L., Perkins, G. and Vassolo, R. (2003), "Business groups and their corporate strategies on the Argentine roller coaster of competitive and anti-competitive shocks", Academy of Management Executive, Vol. 17 No. 3, pp. 32-44.

Cavalieri, S., Gaiardelli, P. and Ierace, S. (2007), "Aligning strategic profiles with operational metrics in after-sales service", Review of International Journal of Productivity and Performance Management, Vol. 56, pp. 436-55.

Chan, R.Y. and Wong, Y.H. (1999), "Bank generic strategies: does Porter's theory apply in an international banking center?”, International Business Review, Vol. 8, pp. 561-90.

Chung, W.W.C., Chan, M.F.S. and Leung, T.S. (2006), "A framework of performance modeling for dynamic strategy", International Journal of Business Performance Management, Vol. 8 No. 1, pp. 62-76.

Claver-Cortes, E., Molina-Azorin, J.F. and Quer-Ramon, D. (2004), “The linkage between strategic groups and firm performance", Management Research, Vol. 2 No. 1, pp. 81-9.

Collis, D.J. and Montgomery, C.A. (2008), “Competing on resources”, Harvard Business Review, Vol. 86 Nos 7/8, pp. 140-50.

Conant, J.S., Mokwa, M.P. and Varadarajan, P.R. (1990), "Strategic types, distinctive marketing competencies and organizational performance: a multiple-measures-based study", Strategic Management Journal, Vol. 11, pp. 365-83.

Cool, K. and Schendel, D. (1988), "Performance differences among strategic group members", Strategic Management Journal, Vol. 9, pp. 207-13.

D’Andrea, G., Ring, L.J., Aleman, B.L. and Stengel, A. (2006), "Breaking the myths on emerging consumers in retailing", International Journal of Retail \& Distribution Management, Vol. 34, pp. 674-87.

Davila, A. and Elvìra, M. (2007), "Psychological contracts and performance management in Mexico", International Journal of Manpower, Vol. 28 No. 5, pp. 384-402.

\section{Retailers in Argentina, Peru and the USA}


$\mathrm{MD}$

49,1

148

Day, G.S. (1994), “The capabilities of market-driven organizations”, Journal of Marketing, Vol. 58 No. 4, pp. 37-52.

DeSarbo, W. and Grewel, R. (2008), "Hybrid strategic groups", Strategic Management Journal, Vol. 29, pp. 293-317.

DeSarbo, W., Di Benedetto, A., Song, M. and Sinha, I.J. (2005), "Revisiting the Miles and Snow strategic framework: uncovering interrelationships between strategic types, capabilities, environmental uncertainty, and firm performance", Strategic Management Journal, Vol. 26, pp. 47-74.

Derajtys, J.M., Chrisman, J.J. and Bauerschmidt, A. (1993), "The shakeout in microcomputers: causes and consequences", Long Range Planning, Vol. 26, pp. 86-97.

Dess, G.G. and Davis, P.S. (1984), "Porter's generic strategies as determinants of strategic group membership and performance", Academy of Management Journal, Vol. 26, pp. 467-88.

Dess, G.G., Gupta, A., Hennart, J.F. and Hill, C.W.L. (1995), "Conducting and integrating strategy research at the international, corporate, and business levels: issues and directions", Journal of Management, Vol. 21, pp. 357-93.

Dranove, D., Peteraf, M. and Shanley, M. (1998), "Do strategic groups exist? An economic framework for analysis”, Strategic Management Journal, Vol. 19, pp. 1029-44.

Dutrénit, G. (2000), Learning and Knowledge Management in the Firm: From Knowledge Accumulation to Strategic Capabilities, Edward Elgar, Cheltenham.

Dutrénit, G. (2004), "Building technological capabilities in latecomer firms: a review essay", Science Technology \& Society, Vol. 9, pp. 209-41.

Dutrénit, G. (2006), Acumulacion de capacidades tecnologicas en subsidiarias de empresas globales in Mexico: El caso de la industria maquiladora de exportacion: Camara de Diputados, LIX Legislatura: Universidad Autonoma Metropolitana, Unidad Xochimilco, Division de Ciencias Sociales y Humanidades, MA Porrua.

Dutrénit, G., Navarro, A.A. and Vera-Cruz, A.O. (2003), "Differencias en el perfil de acumulacion de capacidades tecnologicas en tres empresas Mexicanas", El Trimestre Economico, Vol. 70 No. 1, pp. 109-66.

Dye, R. (2004), "Strategy selection and performance measurement choice when profit drivers are uncertain”, Management Science, Vol. 50, pp. 1624-37.

Eng, L.G. (1994), “Using generic strategies: some caveats”, Singapore Management Review, Vol. 16 No. 1, pp. 43-8.

Feigenbaum, A. and Thomas, H. (2004), "Strategic risk and competitive advantage: an integrative perspective", European Management Review, Vol. 1 No. 1, pp. 84-95.

Feurer, R. and Chaharbaghi, K. (1994), "Defining competitiveness: a holistic approach", Management Decision, Vol. 32, pp. 49-58.

Figueiredo, P. (2001), Technological Learning and Competitive Performance, Edward Elgar, New York, NY and Cheltenham.

Foss, K. and Foss, N. (2005), "Resources and transaction costs: how property rights economics furthers the resource-based view", Strategic Management Journal, Vol. 26, pp. 541-53.

Fulghieri, P. and Hodrick, L.S. (2006), "Synergies and internal agency conflicts: the double-edged sword of mergers", Journal of Economics \& Management Strategy, Vol. 15, pp. 549-76.

Furrer, O., Sudharshan, D., Thomas, M. and Alexandre, M.T. (2008), "Resource configurations, generic strategies, and firm performance”, Journal of Strategy and Management, Vol. 1 No. 1, pp. 15-40. 
Galbraith, C. and Nkwenti-Zamcho, E. (2005), "The effect of management policies on plant-level productivity: a longitudinal study of three US and Mexican small businesses", Journal of Small Business Management, Vol. 43 No. 4, October, pp. 418-31.

Garrigos-Simon, F.J., Marques, D.P. and Narangajavana, Y. (2005), "Competitive strategies and performance in Spanish hospitality firms", International Journal of Contemporary Hospitality Management, Vol. 17 No. 1, pp. 22-38.

Gibbons, R. (2003), "Team theory, garbage cans and real organizations: some history and prospects of economic research on decision making in organizations", Industrial and Corporate Change, Vol. 12, pp. 753-87.

Goh, A.L.S. (2006), "Towards an effective strategy model: conceptual development and qualitative assessment of an integrative typology", International Journal of Management \& Decision Making, Vol. 7 Nos 2/3, pp. 234-53.

Golden, B.R. (1992), "The past is the past - or is it? The use of retrospective accounts as indicators of past strategy", Academy of Management Journal, Vol. 35, pp. 848-60.

Grant, R.M. (1991), "The resource-based theory of competitive advantage: implications for strategy formulation”, California Management Review, Vol. 33 No. 3, pp. 114-35.

Hatten, K.J. and Schendel, D.E. (1977), "Heterogeneity within an industry: firm conduct in the US brewing industry, 1952-1971”, Journal of Industrial Economics, Vol. 26, pp. 97-112.

Hawes, J.M. and Crittendon, W.F. (1984), "A taxonomy of competitive retailing strategies", Strategic Management Journal, Vol. 5 No. 2, pp. 275-87.

Helfat, C. and Peteraf, M. (2003), "The dynamic resource-based view: capability lifecycles", Strategic Management Journal, Vol. 24, pp. 997-1010.

Henderson, R. and Mitchell, W. (1997), "The interactions of organizational and competitive influences on strategy and performance”, Strategic Management Journal, Vol. 18, Summer, special issue, pp. 5-14.

Herbert, T.T. and Deresky, H. (1987), "Generic strategies: an empirical investigation of typology validity and strategic content”, Strategic Management Journal, Vol. 8, pp. 135-47.

Hergert, M.L. (1983), "The incidence and implications of strategic groupings in US manufacturing industries", Harvard University, Boston, MA, unpublished doctoral dissertation.

Hill, C.W.L. (1988), "Differentiation versus low cost or differentiation and low cost: a contingency framework", Academy of Management Review, Vol. 13 No. 3, pp. 401-12.

Hillman, A.J. and Keim, G.D. (2001), "Shareholders, stakeholders and social issue", Strategic Management Journal, Vol. 22, pp. 125-39.

Hoque, Z. (2004), "A contingency model of the association between strategy, environmental uncertainty and performance measurement: impact on organizational performance", International Business Review, Vol. 13, pp. 485-502.

Huselid, M.A. (1995), "The impact of human resource management practices on turnover, productivity, and corporate financial performance", Academy of Management Journal, Vol. 38, pp. 635-72.

Hussey, D. (2002), "Company analysis: determining strategic capability", Strategic Change, Vol. 43 , p. 52.

Husted, B.W. and Allen, D.B. (2006), "Corporate social responsibility in the multinational enterprise: strategic and institutional approaches", Journal of International Business Studies, Vol. 37, pp. 838-49. 
$\mathrm{MD}$

49,1

150

Jackle, A.E. and Li, C.A. (2006), "Firm dynamics and institutional participation: a case study on informality of micro enterprises in Peru", Economic Development and Cultural Change, Vol. 54, pp. 557-78.

Jusoh, R. and Parnell, J.A. (2008), “Competitive strategy and performance measurement in the Malaysian context: an exploratory study", Management Decision, Vol. 46, pp. 5-31.

Kaplan, R.S. and Norton, D.P. (1997), "Why does business need a balanced scorecard?”, Journal of Cost Management, Vol. 11, pp. 5-10.

Katobe, M. and Duhan, D.F. (1993), "Strategy clusters in Japanese markets: firm performance implications", Journal of the Academy of Marketing Science, Vol. 21, pp. 21-31.

Kay, B.H. (1997), “Fijipopulism' and the liberal state in Peru, 1990-1995”, Journal of Interamerican Studies and World Affairs, Vol. 38 No. 4, pp. 55-99.

Ketchen, D.J. and Shook, C.L. (1996), "The application of cluster analysis in strategic management research: an analysis and critique", Strategic Management Journal, Vol. 17, pp. 441-58.

Kim, J. and Mahoney, J.T. (2005), "Property rights theory, transaction costs theory, and agency theory: an organizational economics approach to strategic management", Management and Decision Economics, Vol. 26, pp. 223-42.

Kim, L. (1997), Imitation to Innovation: The Dynamics of Korea's Technological Learning, Harvard Business School Press, Boston, MA.

Kumar, S. and Chase, C. (2006), "Barriers and success factors in the management of international operations: Mexico and China overview", International Journal of Management \& Decision Making, Vol. 7 No. 5, pp. 525-37.

Laitinen, E.K. (2002), “A dynamic performance measurement system: evidence from small Finnish technology companies”, Scandinavian Journal of Management, Vol. 18, pp. 65-99.

Lawless, M.W., Bergh, D.D. and Wilsted, W.D. (1989), "Performance variations among strategic group members: an examination of individual firm capability", Journal of Management, Vol. 15, pp. 649-61.

Lazo, O. (1994), "Two faces of poverty”, World Health, Vol. 94, pp. 16-17.

Leask, G. and Parker, D. (2007), "Strategic groups, competitive groups and performance within the UK pharmaceutical industry: improving our understanding of the competitive process", Strategic Management Journal, Vol. 28, pp. 723-45.

Lenartowicz, T. and Johnson, J.P. (2003), “A cross-national assessment of the values of Latin America managers: contrasting hues or shades of gray?", Journal of International Business Studies, Vol. 34, pp. 266-81.

Lopez, S.V. (2005), "Competitive advantage and strategy formulation: the role of dynamic capabilities", Management Decision, Vol. 43, pp. 661-9.

Luo, Y. and Zhao, H. (2004), "Corporate link and competitive strategy in multinational enterprises: a perspective from subsidiaries seeking host market penetration”, Journal of International Management, Vol. 10, pp. 77-105.

McGahan, A.M. and Porter, M.E. (1997), "How much does industry matter, really?", Strategic Management Journal, Vol. 18, Summer, special issue, pp. 15-30.

McGuinness, T. and Morgan, R.E. (2000), "Strategy, dynamic capabilities and complex science: management rhetoric vs reality", Strategic Change, Vol. 9, pp. 209-20.

Maharajh, L. and Heitmeyer, J. (2005), "Factors that impact United States retailers' expansion into the international marketplace", Journal of Fashion Marketing and Management, Vol. 9 No. 2, pp. 144-55. 
Mauri, A.J. and Michaels, M.P. (1998), "Firm and industry effects within strategic management: an empirical examination", Strategic Management Review, Vol. 19, pp. 211-19.

Miles, R.E. and Snow, C.C. (1978), Organizational Strategy, Structure, and Process, West, New York, NY.

Miles, R.E. and Snow, C.C. (1986), "Organizations: new concepts for new forms”, California Management Review, Vol. 18 No. 3, pp. 62-73.

Miozzo, M. and Grimshaw, D. (2008), "Service multinationals and forward linkages with client firms: the case of IT outsourcing in Argentina and Brazil", International Business Review, Vol. 17, pp. 8-27.

Moore, M. (2005), "Towards a confirmatory model of retail strategy types: an empirical test of Miles and Snow", Journal of Business Research, Vol. 58, pp. 696-704.

Murray, A.I. (1988), “A contingency view of Porter's 'generic strategies”, Academy of Management Review, Vol. 13 No. 3, pp. 390-400.

Nwokah, N.G. (2008), "Strategic market orientation and business performance: the study of food and beverages organizations in Nigeria”, European Journal of Marketing, Vol. 42, pp. 279-86.

Palmer, D.S. (1992), The Shining Path of Peru, St Martin's Press, New York, NY.

Pandza, K. and Thorpe, R. (2009), "Creative search and strategic sense-making: missing dimensions in the concept of dynamic capabilities", British Journal of Management, Vol. 20 No. 1, pp. 118-31.

Parnell, J.A. (1997), "New evidence in the generic strategy and business performance debate: a research note", British Journal of Management, Vol. 8, pp. 175-81.

Parnell, J.A. (2008), "Strategy execution in emerging economies", Management Decision, Vol. 46, pp. 1277-98.

Parnell, J.A., O'Regan, N. and Ghobadian, A. (2006), "Measuring performance in competitive strategy research", International Journal of Management and Decision Making, Vol. 7, pp. 408-17.

Parodi, J. (2000), To Be a Worker: Identity and Politics in Peru, University of North Carolina Press, Chapel Hill, NC.

Peteraf, M.A. (1993), "The corner-stones of competitive advantage: a resource-based view", Strategic Management Journal, Vol. 14, pp. 179-91.

Phelan, S.E., Ferreira, M. and Salvador, R. (2002), "The first 20 years of the Strategic Management Journal', Strategic Management Journal, Vol. 23, pp. 1161-8.

Phillips, L.W., Chang, D.R. and Buzzell, R.D. (1983), "Product quality, cost position, and business performance: a test of some key hypotheses", Journal of Marketing, Vol. 47 No. 2, pp. 26-43.

Pitelis, C.N. (2004), "Edith Penrose and the resource-based view of (international) business strategy", International Business Review, Vol. 13, pp. 523-32.

Pongatichat, P. and Johnston, R. (2008), "Exploring strategy-misaligned performance measurement", International Journal of Productivity and Performance Management, Vol. 57 No. 3, pp. 207-22.

Porter, M.E. (1980), Competitive Strategy, Free Press, New York, NY.

Porter, M.E. (1981), "The contributions of industrial organization to strategic management", Academy of Management Review, Vol. 6, pp. 609-20.

Porter, M.E. (1985), Competitive Advantage, Free Press, New York, NY.

Powell, T.C. (1996), "How much does industry matter? An alternative empirical test", Strategic Management Journal, Vol. 17, pp. 323-34.

\section{Retailers in Argentina, Peru and the USA}

151 
$\mathrm{MD}$

49,1

152

Proff, H. (2002), "Business unit strategies between regionalisation and globalisation", International Business Review, Vol. 11, pp. 231-50.

Punnett, B.J. and Shenkar, O. (1994), "International management research: toward a contingency approach", Advances in International Comparative Management, Vol. 9, pp. 39-55.

Ramanujam, V. and Venkatraman, N. (1987), "Planning system characteristics and planning effectiveness", Strategic Management Journal, Vol. 8, pp. 453-68.

Reed, R. and DeFillippi, R.J. (1990), "Causal ambiguity, barriers to imitation, and sustainable competitive advantage", Academy of Management Review, Vol. 15, pp. 88-102.

Richter, A. and Schmidt, S.L. (2005), "How does strategy process influence strategy content? Antecedents of consistency between resource allocation decisions and corporate strategy", Schmalenbach Business Review, Vol. 57, pp. 332-51.

Robins, J. and Wiersema, M.F. (1995), "A resource-based approach to the multibusiness firm: empirical analysis of portfolio interrelationships and corporate financial performance", Strategic Management Journal, Vol. 16, pp. 277-99.

Roquebert, J.A., Phillips, R.L. and Westfall, P.A. (1996), "Markets vs management: what 'drives' profitability?”, Strategic Management Journal, Vol. 17, pp. 653-64.

Rugman, A.M. and Verbeke, A. (2008), "The theory and practice of regional strategy: a response to Osegowitsch and Sammartino", Journal of International Business Studies, Vol. 39, pp. 326-32.

Selsky, J.W., Goes, J. and Baburoglu, O.N. (2007), "Contrasting perspectives of strategy making: applications in 'hyper' environments”, Organization Studies, Vol. 28, pp. 71-94.

Seth, A. and Thomas, H. (1994), "Theories of the firm: implications for strategy research", Journal of Management Studies, Vol. 31, pp. 165-91.

Sheehan, N.T. and Foss, N.J. (2007), "Enhancing the prescriptiveness of the resource-based view through Porterian activity analysis", Management Decision, Vol. 45, pp. 450-61.

Short, J.C., Ketchen, D.J. Jr, Palmer, T.B. and Hult, T.M. (2007), "Firm, strategic group, and industry influences on performance", Strategic Management Journal, Vol. 28, pp. 147-67.

Sibeck, G.P. and Stage, H.D. (2001), "Aspects of comparative management in selected Mexican and Peruvian firms", International Journal of Organization Theory \& Behavior, Vol. 4 Nos 1/2, pp. 91-102.

Sorge, A. and Brussig, M. (2003), “Organizational process, strategy content, and socio-economic resources: small enterprises in East Germany, 1990-1994”, Organization Studies, Vol. 24, pp. 1261-81.

Spanos, Y.E., Zaralis, G. and Lioukas, S. (2004), "Strategy and industry effects on profitability: evidence from Greece”, Strategic Management Journal, Vol. 25, pp. 139-65.

Sully de Luque, M.F. and Arbazia, L.A. (2005), "The complexity of managing human resources in Peru”, International Journal of Human Resource Management, Vol. 16, pp. 2237-53.

Thomas, H. and Pollock, T. (1999), "From I-O economics' S-C-P paradigm through strategic groups to competence-based competition: reflections on the puzzle of competitive strategy", British Journal of Management, Vol. 10, pp. 127-40.

Thomas, H. and Venkatraman, N. (1988), "Research on strategic groups: progress and proposals", Journal of Management Studies, Vol. 25, pp. 537-55.

Tywoniak, S., Galvin, P. and Davies, J. (2007). "New Institutional Economics' contribution to strategic groups analysis", Managerial and Decision Economics, Vol. 28 No. 3, pp. 213-28

Van der Stede, W.A., Chow, C.A. and Lin, T.W. (2006), "Strategy, choice of performance measures, and performance”, Behavioral Research in Accounting, Vol. 18, pp. 185-205. 
Varadarajan, P.R. (1999), "Strategy content and process perspectives revisited", Academy of Marketing Science, Vol. 27 No. 1, pp. 88-100.

Veett, N.M.K., Ghobadian, A. and Gallear, D. (2009), "Business-level strategy and performance evidence from manufacturing firms", paper presented at the Annual Meeting of the Academy of Management, Chicago, IL.

Venkatraman, N. and Ramanujam, V. (1986), "Measurement of business performance in strategy research: a comparison of approaches", Academy of Management Review, Vol. 11, pp. 801-14.

Wernerfelt, B. (1984), “A resource-based theory of the firm”, Strategic Management Journal, Vol. 5, pp. 171-80.

Weyzig, F. (2006), "Local and global dimensions of corporate social responsibility in Mexico", Journal of Corporate Citizenship, Vol. 29, pp. 69-81.

Whinston, M.D. (2003), "On the transaction cost determinants of vertical integration", Journal of Law, Economics \& Organization, Vol. 19 No. 1, pp. 1-24.

Wright, P. (1987), “A refinement of Porter's strategies”, Strategic Management Journal, Vol. 8 No. 1, pp. 93-101.

Zahra, S.A. and Covin, J.G. (1993), "Business strategy, technology policy and firm performance", Strategic Management Journal, Vol. 14, pp. 451-78.

\section{Further reading}

Parnell, J.A., Dent, E., Hughes, T. and O'Regan, N. (2009), "The scholar-practitioner gap: luck and causality", paper presented at the 2009 Academy of Management Conference, Chicago, IL.

\section{Appendix}

Survey items

Cost leadership (Zahra and Covin, 1993)

COST1 Efficiency of securing raw materials or components.

COST2 Finding ways to reduce costs.

COST3 Level of operating efficiency.

COST4 Level of production capacity utilization.

COST5 Price competition.

Differentiation (Zahra and Covin, 1993)

DIFF1 Using new methods and technologies to create superior products.

DIFF2 New product development.

DIFF3 Rate of new product introduction to market.

DIFF4 Number of new products offered to the market.

DIFF5 Intensity of advertising and marketing.

DIFF6 Developing and utilizing sales force.

DIFF7 Building strong brand identification. 
Focus (Zahra and Covin, 1993)

49,1

FOCUS1 Uniqueness of products in function or design.

FOCUS2 Targeting a clearly identified segment.

FOCUS3 Offering products suitable for a high price segment.

FOCUS4 Offering specialty products tailored to a customer group.

Relative competitive performance (Ramanujam and Venkatraman, 1987)

PERF1 Sales growth.

PERF2 Growth in profit after tax.

PERF3 Market share.

PERF4 Return on assets (ROA).

PERF5 Return on equity (ROE).

PERF6 Return on sales (ROS).

PERF7 Overall firm performance and success.

PERF8 Competitive position.

Marketing capabilities (DeSarbo et al., 2005)

Knowledge of customers.

Knowledge of competitors.

Integration of marketing activities.

Skill to segment and target markets.

Effectiveness of pricing programs.

Effectiveness of advertising programs.

Market linking capabilities (DeSarbo et al., 2005)

Market sensing capabilities.

Customer-linking (i.e. creating and managing durable customer relationships) capabilities.

Capabilities of creating durable relationship with our suppliers.

Ability to retain customers.

Channel-bonding capabilities (creating durable relationship with channel members such as whole sellers, retailers, etc.).

Relationships with channel members.

Technology capabilities (DeSarbo et al., 2005)

New product development capabilities.

Manufacturing processes.

Technology development capabilities.

Ability of predicting technological changes in the industry.

Production facilities.

Quality control skills. 
Management capabilities (DeSarbo et al., 2005)

Integrated logistics systems.

Cost control capabilities.

Financial management skills.

Human resource management capabilities.

Accuracy of profitability and revenue forecasting.

Marketing planning process.

\section{Corresponding author}

John A. Parnell can be contacted at: jparnell@pucp.edu.pe
Retailers in Argentina, Peru and the USA

155

To purchase reprints of this article please e-mail: reprints@emeraldinsight.com Or visit our web site for further details: www.emeraldinsight.com/reprints 
Reproduced with permission of the copyright owner. Further reproduction prohibited without permission. 